\title{
U.S DRONE STRATEGY IN WAR AGAINST TERRORISM AND ITS REPERCUSSIONS ON PAKISTAN'S NATIONAL SECURITY
}

\author{
Dr. Zubaida Aziz \\ Assistant Professor \\ Department of Political Science \\ Federal Urdu University Karachi, Pakistan \\ Zubaida.gondal@yahoo.com \\ Dr. Rani Erum \\ Assistant Professor \\ Department of Political Science \\ Federal Urdu University Karachi, Pakistan \\ http://www.rani.irum@fuuast.edu.pk \\ https://orcid.org/0000-0002-3845-8899
}

\begin{abstract}
Respective research intended to examine the effect of the US drone strategy on Pakistan's national security. It is based on the diverse opinion of analysts some of whom suggest that these incursions were the clear defilement of International Law and sovereignty of Pakistan thus enhancing resentment provoking more terrorism. Others argue the effectiveness of drone attacks against terrorists. Though unpopular these strikes have helped U.S. counterterrorism efforts in Pakistan. As a partner of America in the war against terror, Pakistan is being adversely affected by this strategy. It has resulted in not only civilian casualties but has further provoked terrorists to retaliate thus affecting internal security and law and order concerns of Pakistan. Should these strikes continue or be abandoned altogether or be brought within a prescribed format is now the issue of concern. This will be dealt with considering various approaches, implications, and regulations.
\end{abstract}

KEYWORDS: UAVs, Counter-Terrorism, Safe havens, Surveillance, Drone warfare, suicidal Bombing. 


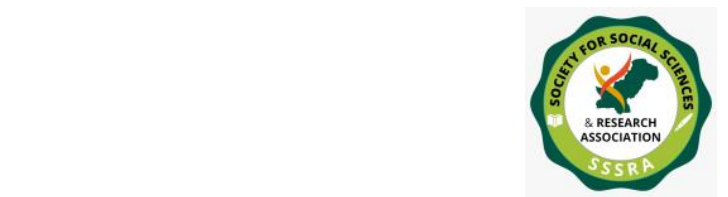

Pak. Journal of Int'L Affairs, Vol 4, Issue 1 (2021)

U.S Drone Strategy In War Against ...

\section{INTRODUCTION}

Drones have become an important contrivance of the United States in the WAT and against confrontational groups. Such use of drones has growingly become the focus of worldwide debate particularly; inside Pakistan. Regardless of all excitement about drone strikes, the relative data is insufficient and without complete facts. Due to the secret classified CIA program, the data collection on drone strikes is not easy. On the other hand government of Pakistan never officially accepted the association with the US in this program. The only source was the leaked information gathered by different reporters (Becker \& Shane, 2012). Therefore, there is no way to authorize all those statistics are exactly reveal the real procedure by which drone attacks are decided and conceded (Miller, 2012). In addition, the U.S. government never vocal upfront about the drone strategy; therefore scholars have no other option left, except to gather information from other possible sources.

Mostly accessible information related to drone strikes is accumulated from official sources, by the US or in the affected state. The affected areas are in Pakistan, FATA (Federally Administrated Tribal Area) is not within the reach of the national and international media and scholars. Thus, there are nearly no available authentic records about the attacks and sufferings of drone assaults, hence reaching definite ends is tremendously hard.

\section{TECHNOLOGY OF DRONES}

The drone personified the extraordinary technology of artillery: sophisticated in the act, smooth in look, and swift in performance. It was enigmatic, reserved, fatal, and extremely bereft of mortal existence. It is the note of devastation by the names of Slayer and eradicator (Ahmed, 2013). Officially titled American unmanned aerial vehicles (UAVs), can mutely detect a person, cluster, or site for hours, but act swiftly without endangering a pilot's life. It is a Remote control aircraft roughly 27 feet long with a 55-foot wingspan. It is capable of inspection as well as has ground strikes capability with two Hellfire missiles in the MQ-1B and the ability of resounding laser-guided bombs on the MQ-9 (Krock, 2002). They can remain concealed from radar, thus can serve near 50,000 feet on land, which makes to a vital intelligence and rapid warfare device (Ibid). It can be controlled from any part of the world with the help of satellites. This blend of skills is exceptional and has permitted the U.S to thrash the safe heavens of al-Qaeda and intrude on the actions of other radical factions. 


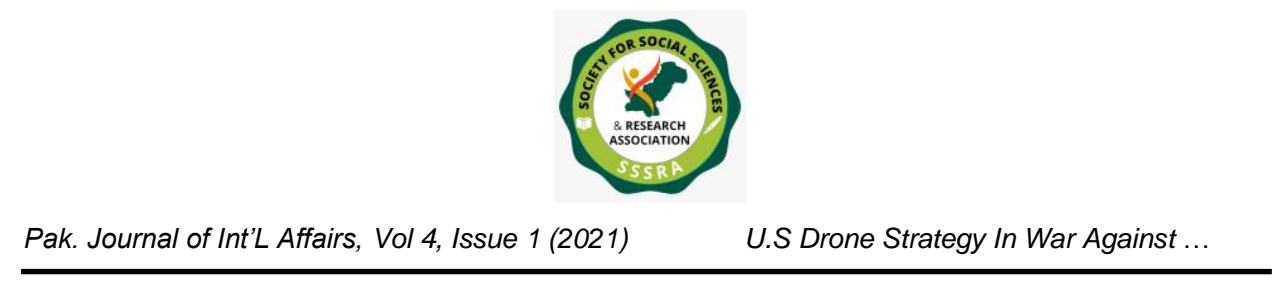

\section{LEGAL STATUS OF DRONE STRIKES}

The US drone forays are often criticized on legal grounds. The United States litigating the strikes is validly allowed. Although the administration has not yet presented any law in favor of the use of drones in extra-jurisdiction beset bloodsheds (Frieden, 2012). The failure in providing legal justification accuses the US of profane global legitimate outlines on national force and sovereignty (Bowcott, 2012). Moreover, analysts claimed that US drone programs in some countries set a treacherous model that could lead others to use parallel strategies in a "global drone war"(Morely, 2012). The Article 51 of the United Nations Charter, a state has

"The inherent right of individual or collective self-defense [sic]" until the UN Security Council takes action (Charter of UNO).

Which use as in favor of the usage of interstate force against another nation's territory during times of peace. Whereas the other group of analysts placed Article 20 of the United Nations' "Responsibility of States for Internationally Wrongful Acts". Therefore drone incursions infringe the Charter of United Nations, Rome Statute of International Criminal Court, and the Geneva Conventions of 1949. Article 2(4) of the UN Charter states "All Members shall refrain in their international relation from the threat or use of force against the territorial integrity or political independence of any state or in any other manner inconsistent with the Purposes of the United Nations". (UN Charter, 1945)

The strikes also break articles of the Additional Protocol I; Article 51(2) states "The civilian population and individual civilians shall enjoy general protection against dangers arising from military operations".

Article 51(5) states "Among others, the following types of attacks are to be considered as indiscriminate":

(a) "An attack by bombardment by any methods or means which treats as a single military objective several separated and distinct military objectives located in a city, town, village or other area containing a similar concentration of civilians or civilian objects;"

(b) "An attack which may be expected to cause incidental loss of civilian life, injury to civilians, damage to civilian objects, or a combination thereof, which would be excessive to the concrete and direct military advantage." (UN Charter, 1945)

Similarly, International Covenant on Civil and Political Rights (ICC-PR), which has been certified by the US, rules out extrajudicial killing. According to Article 6(1) "every 


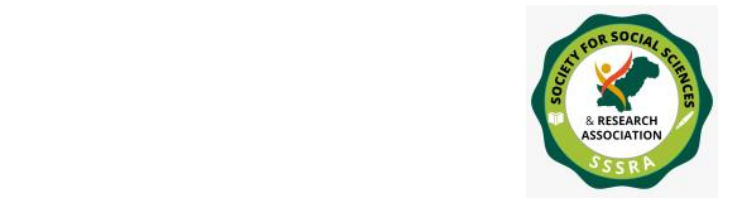

individual has the inherent right to life and no one shall be arbitrarily deprived of his life." According to Article 6(2) "in countries which have not abolished the death penalty, sentence of death may be imposed only for the most serious crimes following the law in force at the time of the commission of the crime and not contrary to the provisions of the present Covenant and the Convention on the Prevention and Punishment of the Crime of Genocide. This punishment can only be carried out under a final judgment rendered by a competent court." (UN Charter, 1945)

The US committed 414 drone strikes in Pakistan from 2004 to 2018, mostly targeted on FATA, particularly North Waziristan, South Waziristan, and Kurram agencies. The tribal region was in federal control with limited political rights. Drones attacks largely occurred in Pashtun areas, where people generally not very fond of the military. Most of the surveys clarified that locals do not trust on Pakistani Army (Shinwari, 2011). The attacks have wiped out numbers of important most wanted militant commanders including al-Qaeda leaders and Pak/Afghan Taliban but also notches several acquitted citizens. Pakistan is failed to compel its statutory responsibility to safeguard the lives of its citizens on its land. The country was not in a war situation or even in that case, Islamabad would still be indulged to safeguard their citizens from the U.S actions, at least, it had to ensure the principles of peculiarity and proportionality under International Humanitarian Law (IHL) (Rogers, 2010).

The table gives the complete detail of drone strikes in Pakistan and their effects. 
DRONE ATTACK IN PAKISTAN: 2004-2018

\begin{tabular}{|c|c|c|}
\hline Year & Incidents & Killed \\
\hline 2004 & 1 & 7 \\
\hline 2005 & 3 & 15 \\
\hline 2006 & 0 & 0 \\
\hline 2007 & 1 & 20 \\
\hline 2008 & 19 & 156 \\
\hline 2009 & 46 & 536 \\
\hline 2010 & 90 & 831 \\
\hline 2011 & 59 & 548 \\
\hline 2012 & 46 & 344 \\
\hline 2013 & 24 & 158 \\
\hline 2014 & 19 & 879 \\
\hline 2015 & 14 & 85 \\
\hline 2016 & 03 & 07 \\
\hline 2017 & 08 & 43 \\
\hline 2018 & 13 & $33-68$ \\
\hline Total & $\mathbf{4 1 4}$ & $\mathbf{2 0 8 5 7}$ \\
\hline
\end{tabular}

(Data till July 4, 2018)

Source of Table:

http://www.satp.org/satporgtp/countries/pakistan/database/Droneattack.htm

The table illustrates the rapid growth the drone attacks awing the last decade. There have been a total of 414 attacks till July, $4^{\text {th }}, 2018$. The highest number of strikes took place in 2010 while there was no attack in 2006. After 2010 a slow decline can be seen in drone strikes. To sum it, the above table exhibits increase and then a decrease in attacks which is an indication of the effectiveness of UAVs in the tribal area of Pakistan.

\section{MILITARY PERSPECTIVE OF DRONES}

From the US defense perspective, drone warfare is an effective tactic in the WAT and countering terrorism. They believed that drone attacks are precise and accurate to achieve targets without risking the lives of their soldiers also can target terrorist movement, and eliminate the threats immediately once they exposed in those places that are almost unreachable to man. These strikes are led under the CIA which emphasizes that military affairs have been changed since $9 / 11$ as they clearly stated: 


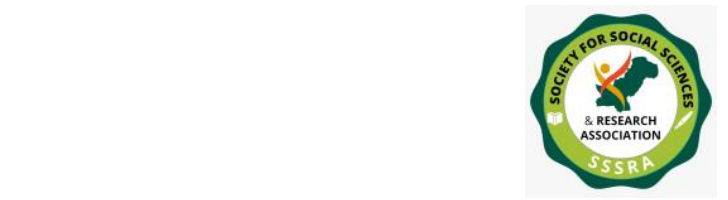

U.S Drone Strategy In War Against ...

CIA formally established the joined elements under the Associate Director for Military Affairs (ADMA) in 2007. Today, ADMA is jointly manned by Agency and uniformed military professionals, operating as one team to coordinate, plan, execute, and sustain joint CIA and DOD worldwide activities based upon priorities established by the Director of the CIA, to achieve National Security objectives (CIA, 2013).

The U.S forces have launched its drone policy under the CIA and the Department of Defense (DOD), but the extended range of such operations is always been questioned since the program was started. The facts highlighted that the US drone strategy has not ended any culprit organization utterly but only disturbed them. Brian Williams believed that 'every new US regime has kept this tactic from the previous administration knowingly as 'its best, "worst option" in the fight against Al Qaeda and the Taliban'. Furthermore, he also highlights the dual face of Pakistan's officials who publically condemn the strikes, and furtively abide them' (Brian, 2011). This ruthless acceptance by the Pakistani government is often obliviously discussed in media and elsewhere. Nonetheless, the U.S continued its drone strategy till 2018, even though it had failed in eliminating any terrorist group.

The military view is the only angle that remains silent on the failure of their drone policy, and still defending its effectiveness with the acute modifications. Although it is the clear acceptance of defeat CIA is not officially accepted it, due to the conceivable response of all factions from every corner of the world. Yet, it appears that the U.S seems to be unaware of the worldwide view and still reluctant to maintain optimistic relations with affected countries such as Pakistan.

\section{PAKISTAN'S OFFICIAL POSITION ON DRONES}

Pakistan's official stance towards drones is ambiguous. Rather than integrally opposing the drone attacks on its soil, the political leadership generally prefers to be quiet or deliberately avoid the issue, whereas, the military was keener on attainment for more control over optimal targets, mostly to chastise nemeses. Sometimes, they ostensibly guard radicals who are good with them, or some radical groups with whom the forces have made peace contracts. It is yet evident that Pakistan has not submitted an official complaint to the UNSC or any other international forum. It constantly clear airspace for the drones, which the US administration interprets as tacit consent (Entous, et al, 2012). Ample signs exist of implied Pakistani approval and vigorous assistance with the drone program including acknowledgments by General Musharraf in April 2013 and former 


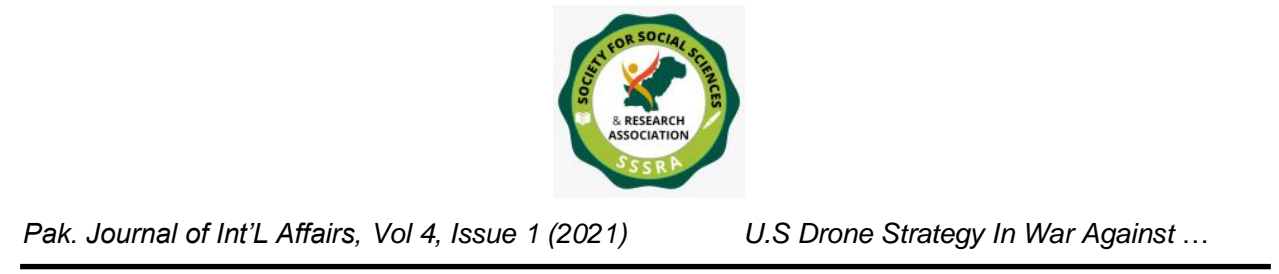

Prime Minister Gilani in 2008 and 2010, challenging the official stance that it infringes the state's authority.

Moreover, in September 2012, then-Foreign Minister Hina Rabbani Khar stated, "the use of unilateral strikes on Pakistani territory is illegal" but while accusing independent attacks, Khar also articulated her regime's provision for the plan's goal: "What the drones are trying to achieve, we may not disagree. If they're going for terrorists, we do not disagree but we have to find ways which are lawful, which are legal" (AFP, 2012). Although the intelligence-sharing deteriorated in 2011 and 2012, official consultations were continued between both countries. CIA Director Leon Panetta while visiting Pakistan was mainly vigorous about getting more authority to fly drones in more areas in the tribal areas (Schmitt \& Mazzetti, 2011). ISI chief General Zaheerul Islam's was allegedly aimed at looking for "direct control of predators (drones) for perfect attacks and for reducing their dogmatic consequences" during his visit to the U.S in July 2012 (Spymaster 2012).

\section{PSYCHOLOGICAL EFFECTS OF DRONES STRIKES IN PAKISTAN}

Local demises, grievances, shifts, and assets loss instigated agony in common Pakistani citizens. Furtive drone incursions have their knell, unexpected attacks with no prior indications are difficult to engross by a common villager of remote areas. People who were suffering from collateral damage without any crime receives no condolences from any faction. They did not receive any apology or explanation of their grief. Moreover, no one comes upfront to take responsibility for their disturbing lives under the constant watch of surveillance drones (Perlez \& Shah, 2010). Sometimes that surveillance buzz was continued for 24 hours a day in the northern province which traumatized people and created psychotic issues. Michael Kugelman of the Woodrow Wilson International Center for Scholars notes:

I have heard Pakistanis speak about children in the tribal areas who become hysterical when they hear the characteristic buzz of a drone. [...] Imagine the effect this has on psyches, and particularly on young ones already scarred by war and displacement (Kugelman, 2012).

An investigator at the UK charity, Reprieve, who met a young man named Tariq Aziz shortly before he was killed in a March 17, 2011 strike, reported: "I asked him, 'Have you seen a drone,' and I expected him to say, 'Yes, I see one a week.' But he said they 


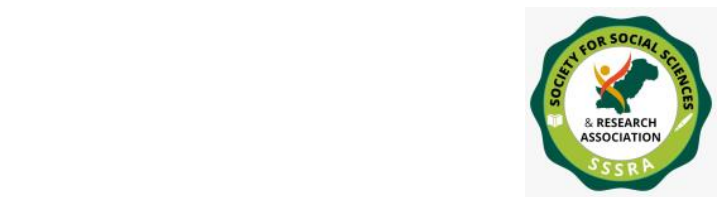

saw 10 or 15 every day. And he was saying at night time, it was making him crazy because he couldn't sleep. All he was thinking about at home was whether everyone was okay. I could see it in his face. He looked terrified" (Schifrin, 2011). Thus losses and destruction of property may affect some people, but the dread related to clandestine drone forays disturbs almost everyone. NGOs may occasionally offer aid to drone-affected people in remote areas, but most of them practically lost everything and need complete assistance in circumstances where no one has accepted their damage's responsibility thus, no compensation or assistance either from the US or Pakistani Government.

\section{INCREASE IN DOMESTIC MILITANCY AND SUICIDE BOMBING IN PAKISTAN}

Despite civilian deaths, damages, dislodgment, and property loss, increase in domestic militancy and suicide bombing are the other impacts on Pakistan which grow even greater due to drone strikes. Although both of these issues started after the cooperation of Pakistan in the US war on terror but picked up speed during the years when drone attacks on tribal areas of Pakistan were casual. Tehrik-e-Taliban Pakistan is the byproduct of these attacks increase and played a very important role in most of the suicide bombing and other terrorist activities all over Pakistan. Their victims are not only civilians but also government and military officials. It is a fact that Pakistan has experienced an unbelievable escalation in suicide attacks after the Lal Masjid operation by the security forces in July 2007 (Akhlaque, 2007). There were 42 suicide attacks before the operation, but after that $100 \%$ increase had been seen. The table gives complete detail about such attacks during 2002-2017 not because of occupation by foreign forces but for being an ally of the US.

SUICIDE ATTACK IN PAKISTAN: 2002-2018

\begin{tabular}{|c|c|c|c|}
\hline Year & Incident & Killed & Injured \\
\hline 2002 & 01 & 15 & 34 \\
\hline 2003 & 02 & 69 & 103 \\
\hline 2004 & 07 & 89 & 321 \\
\hline 2005 & 04 & 84 & 219 \\
\hline 2006 & 07 & 161 & 352 \\
\hline 2007 & 54 & 765 & 1677 \\
\hline 2008 & 59 & 893 & 1846 \\
\hline 2009 & 77 & 949 & 2356 \\
\hline 2010 & 49 & 1167 & 2199 \\
\hline
\end{tabular}




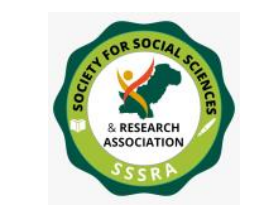

Pak. Journal of Int'L Affairs, Vol 4, Issue 1 (2021)

U.S Drone Strategy In War Against ...

\begin{tabular}{|c|c|c|c|}
\hline 2011 & 41 & 628 & 1183 \\
\hline 2012 & 39 & 365 & 607 \\
\hline 2013 & 37 & 719 & 1293 \\
\hline 2014 & 25 & 336 & 601 \\
\hline 2015 & 19 & 161 & 360 \\
\hline 2016 & 19 & 401 & 935 \\
\hline 2017 & 07 & 134 & 476 \\
\hline 2018 & 11 & 61 & 132 \\
\hline Total & $\mathbf{4 7 9}$ & $\mathbf{7 2 9 1}$ & $\mathbf{1 5 4 2 8 +}$ \\
\hline
\end{tabular}

Data till June17, 2018

http://www.satp.org/satporgtp/countries/pakistan/database/Fidayeenattack.htm

The first terrorist suicide attack happened in 2002, killing 15 people while 34 were injured making a total of 49 victims. A gradual increasing trend can be seen in the incidents from 2002 to 2006 targeting more people with each attack. The number jumped from 7 to 54 attacks in just a year. In 2007, 54 suicidal attacks took place, resulting in 765 deaths and 1677 injured people portraying suicide attacks as a swift killing strategy and suicide bombers became the most devastating phenomenon for the internal security of Pakistan. This rapid increase in the attacks created an atmosphere of terror and uncertainty in the country. Since then the attacks have been increasing in numbers every year and casualties have crossed the limits of the patience of the people of Pakistan.

\section{U.S STANCE ON CIVILIAN DEATHS}

White House never accepted the actual number of innocent deaths by secret drone operations. The officials emphasize fewer civilian deaths on Pakistan soil by US attacks. One of the Obama Administration officials has claimed only 20 to 50 non-combatant deaths have happened since 2008 (Capaccio \& Bliss, 2011). A similar claim was occurred by other officials, who believed that just 50 civilians were killed from 2001 to 2011, or less than $2.5 \%$ of people were losing their lives from drone strikes (Shane, 2011). The New York Times reported in May 2012, by an administration official that civilian losses from drone strikes in Pakistan during the Obama era were in the "single digits," probably meaning over a year (Becker \& Shane, 2012). The data provided by US officials were contradictory because they were glued with the digit of 50 in 2008 and 2010 even in 2011 (Delanian, 2011). The information from the CIA was continuously given without facts or civilian death details which raised many questions on its authenticity. Government officials back up their claims because they do not have any backup strategy of evading forays that might result in civilian deaths 


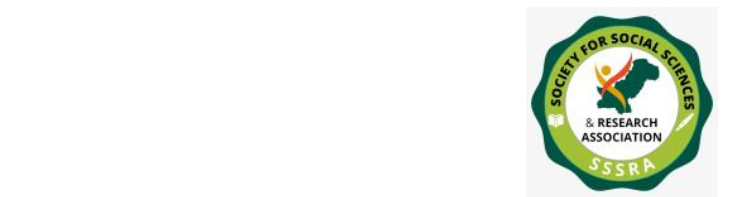

Pak. Journal of Int'L Affairs, Vol 4, Issue 1 (2021)

U.S Drone Strategy In War Against ...

\section{PAKISTAN'S POLITICAL STANCE ON DRONES}

Pakistan's Prime Minister Nawaz Sharif, stated in United Nations General Assembly: My country condemned terrorism "in all its forms and manifestations", but the use of drone strikes could never be accepted as it was "a continued violation of our [Pakistan's] territorial integrity (Gull, 2013).

All major political parties in Pakistan have already professed their disagreement with these assaults in a declaration on 28 December 2010, finding them "tantamount to compromising the sovereignty of Pakistan" (Nawaz, 2011). Faisal Karim Kundi, thenNational Assembly deputy speaker said:

Not a single political party supports drones. But what can we do aside from ordering our air force to shoot them down? This would mean declaring war on a superpower (Crisis Group Interview, 2013).

The Peshawar High Court (PHC) in Pakistan professed on May 9, 2013, that United States drone strikes illegitimately ruptured state authority and was in "blatant violation of Basic Human Rights" and provisions of the Geneva Conventions. The court gave this verdict on complaints of political parties and citizens who were the victims of the attacks. It was the first legal verdict against drone actions in Pakistan by any Pakistani court. The court not only condemn attacks but mentioned their legal status and ordered the government to make every effort to cease these actions; as well as to take the issue in the UN Security Council and "constitute an independent War Crimes Tribunal". The court also requested that the Security Council or General Assembly pass a resolution condemning the drone strikes (Horowitz \& Rogers, 2013). There is a clear difference in the public opinion and official position of the country. Official stance generally made by military whereas the political leadership's response, is based on their approach to the high command of armed forces, therefore, its intensity regularly fluctuates. Officially political factions get information through a variety of means, including briefings given to parliament by the army chief and ISI director general (Shaheen, 2011).

\section{ROLE OF MEDIA IN CREATING AWARENESS REGARDING U.S DRONE STRATEGY}

Generally, media played the role of the third pillar of the government. The $21^{\text {st }}$ century exhibited its role in the true sense. Particularly the awareness created by media during the drone war is commendable because the region which was affected is beyond public reach 


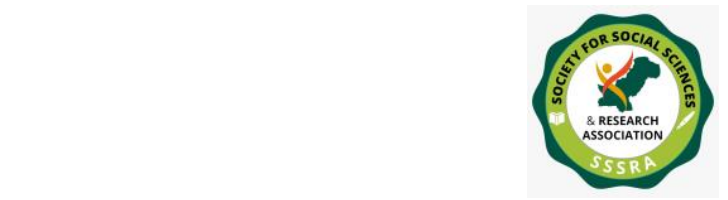

Pak. Journal of Int'L Affairs, Vol 4, Issue 1 (2021)

U.S Drone Strategy In War Against ...

therefore, media become the only credible source of information. According to Kaltenthaler, Miller, and Fair:

One of the major reasons why drone strikes have become such a salient issue among so much of the Pakistani general public is that there is a large amount of media coverage of the drone issue. The killing of major Al Qaeda, Pakistani or Afghan Taliban figures gets regular coverage in the Pakistani print media (Such as the newspapers Dawn in English and Jang in Urdu), as well as television and radio. But the collateral damage from drone strikes also gets major play in the Pakistani media outlets (Karl, et al, 2012).

The continued reporting of drone attacks in the media awakened the public and it became difficult for both Pakistan and the US regime to continue it vigorously. The pictures of devastation homes of innocent peoples and interviews of victims bothered both regimes' policymakers. The constant highlight reel of US drone attacks, increased anti-U.S feeling in every corner of Pakistan which reported by reporters and neutrals around the sphere, has led to the growing annoyance to the strategy. As Bauman and Lyon asserts that:

Everything private is now done, potentially in public, and is potentially available for public consumption: and remains available for the duration, till the end of time, as the Internet cannot be made to forget (Bauman \& Lyon, 2013).

Therefore, the reporting of the media and globalization of social media has alleviated the growth of anti-U.S emotions, and the pictures of ammo explosion and slaughtering civilians have become a leading force in the debate of the efficacy of the policy.

\section{CONCLUSION}

The repercussions of American drone strikes in Pakistan are profound, for one or terrorist killing of ten or more innocent poor non-combatants including children, women, and senior citizens, by the United States is hard to justify on any platform (Rashid, 2012) however sustaining public outrage against the U.S. Since the Pakistani media coverage increases, numerous public protests against the drones in Pakistan's major cities have been seen on daily bases. The first reason for these protests is the psychological consequences of attacks on the people of Waziristan. They were suffering from anxiety, dread, rage, and petulance which completely intrude on the people of Pakistan (Wood, 2012). Secondly, drone operations are a peril to the state's autonomy. The nation allows its government to take measures against terrorists but at the same time, they have not allowed American invasion at any cost. However, the U.S has gravely underestimated 
Pakistanis' hostility towards drone attacks. Although America has tried to convince the Pakistani public about the merits of drone operations in FATA it looks like a lost cause. US authorities have also realized that this is an impossible task to convince the people of Pakistan. Therefore the oratory from US State Department officials in Pakistan has shifted from creating the understanding regarding the need for drones towards the understanding of decrease in the number of drone attacks in FATA significantly also promising to end them altogether soon by the withdrawal of US troops from Afghanistan. The United States rethink its policy and altered it immensely. In reviewing counterterrorism tactics along the Afghani border, the U.S. reconsider drone warfare and recognized the impact that drone strikes created not only on terrorist groups' but also on US image in the world and gradually reduced it inside Pakistan. Indications also suggest that drone programs will continue in other parts of the world but they will not effective anymore in Pakistan. However, drone attacks are lethal from the US perspective and they use it in multiple regions today in covert and overt operations. 


\section{REFERENCES:}

AFP. 28 September 2012. Pakistan backs drones' aim, not method: Minister", The Express Tribune, Retrieved from http://tribune.com.pk/story/443740/pakistanbacks-drones-aim-not-method-minister/20. March. 2017

Ahmed, Akbar. 2013. The Thistle and the Drone: How America's War on Terror Became

Akhlaque, Qudsia. July 11, 2007. "Its Operation Sunrise, not Silence, "The daily Dawn, Retrieved from http://www.dawn.com/2007/07/12/top7.htm. 17. April. 2017

Albritton, Chris. January 22, 2012. "Exclusive: How Pakistan Helps the U.S. Drone Campaign," Reuters

Bauman, Zygmunt \& Lyon, David. 2013. Liquid surveillance: a conversation, Oxford: John Wiley \& Sons

Becker, Jo \& Shane, Scott. 29 May 2012. "Secret 'Kill List' Proves a Test of Obama's Principles and Will," The New York Times, Retrieved from http://www.nytimes.com/2012/05/29/world/obamas-leadership-in-war-on-alqaeda.html?pagewanted=all 22. March. 2017

Benjamin, Medea. 2013. Drone warfare: killing by remote control, New York: Verso Books

Bergen, Peter \& Tiedmann, Katherine. July/August 2011. "Washington's Phantom War," Foreign Affairs, Retrieved from http://www.foreignaffairs.com/articles/67939/peter-bergen-and-katherinetiedemann/washingtons-phantom-war 17. March. 2017

Bowcott, Owen. 21 June 2012. "Drone strikes threaten 50 years of international law, says UN rapporteur," The Guardian, Retrieved from http://www.guardian.co.uk/world/2012/jun/21/drone-strikes-international-law-un 20. March. 2017 
Brulliard, Karin \& Khan, Haq Nawaz. September 18, 2011. Pakistani officials say troops, Taliban Militants Clashed over Downed Drone," Washington Post, Retrieved from http://www.washingtonpost.com/world/war-zones/pakistani-military-andtaliban-militants-fight-over-downed-drone/2011/09/18/gIQABO6VcK_story.html 15. March. 2017

Bruno, G. 2010, July 19. Drone Activities in Pakistan. from Council on Foreign Relations, Retrieved from http://www.cfr.org/publication/22659/us_drone_activities_in_pakistan.html16. March. 2017

Capaccio Tony and Bliss, Jeff. January 31, 2011. "US Said To Reduce Civilian Deaths After Increasing CIA Pakistan Strikes,” Bloomberg News

Charter of the United Nations, Chapter I: Purposes and Principles, Retrieved from http://www.un.org/en/documents/charter/chapter1.shtml. 20. March. 2017

Charter of the United Nations, "Article 51," Retrieved from http://www.un.org/en/documents/charter/chapter7.shtml 20. March. 2017

CIA. 2013. 'What we do.' Retrieved from https://www.cia.gov/offices-of-cia/militaryaffairs/history.html, 15. March. 2017

Clarke, Richard. 02 December 2012. "Give drones a medal,” New York Daily News, Retrieved from http://www.nydailynews.com/opinion/give-drones-medal-article$\underline{1.1211249}$ 20. March. 2017

Coll, Steve. September 10, 2001. Ghost Wars: The Secret History of the CIA, Afghanistan, and bin Laden, from the Soviet Invasion.

Crisis Group interview. 01 February 2013. Islamabad, Retrieved from http://www.crisisgroup.org/ /media/Files/asia/south-asia/pakistan/247-dronesmyths-and-reality-in-pakistan.pdf 16. March. 2017

Dawoud, Khaled. 18 November 2001. "Mohammed Atef," The Guardian, Retrieved from http://www.guardian.co.uk/news/2001/nov/19/guardianobituar-ies.afghanistan 
Department of Defense, Report to Congress on Future Unmanned Aircraft Systems Training, Operations, and Sustainability. April 2012. Retrieved from http://www.fas.org/irp/program/collect/uas-future.pdf

Dilanian, Ken. February 22, 2011. "CIA Drones May Be Avoiding Pakistani Civilians," Los Angeles Times, Retrieved from http://articles.latimes.com/2011/feb/22/world/la-fg-drone-strikes-20110222 20. March. 2017

Entous, Adam, Gorman, Siobhan and Perez, Evan. September 26, 2012. "U.S. Unease Over Drone Strikes," Wall Street Journal

Foust, Joshua. January 2013. Understanding the Strategic and Tactical Considerations of Drone Strikes, Retrieved from http://www.AmericanSecurityProject.org 20. March. 2017

Foust, Joshua and Boyle, Ashley S. August 16, 2012. The Strategic Context of Lethal Drones: A framework for discussion, Retrieved from http://americansecurityproject.org/ASP\%20Reports/Ref\%200077\%20\%20The\%2 0Strategic\%20Context\%20of\%20Lethal\%20Drones.pdf 02. April. 2017

Frieden, Terry. 2012. "Holder: Not 'assassination' to target Americans in terror hunt," CNN's Security Clearance blog, Retrieved from http://security.blogs.cnn.com/2012/03/05/holder targeting-american-terrorists-notassasination/ 10. April. 2017

Gray, Christine D. 2000. International Law and the use of Force ,New York: Oxford University Press

Guiding Principles applicable to unilateral declarations of States capable of creating legal obligations, Retrieved from http://untreaty.un.org/ilc/texts/instruments/english/draft\%20articles/9 6 200.pdf 10. March. 2017

Gul, Ayaz. Oct 22 2013. "Pakistani PM Urges US to Stop Drone Strikes"

Iqbal, Khuram. February 15, 2010. "Strategic measures to counter suicide terrorism in Pakistan," Pak Institute for Peace Studies Report, Retrieved from http://sanpips.com/index.php?action=ra\&id=pvt_list_1 15. March. 2017 
Jonathan, Horowitz, \& Rogers. 28 May, 2013. Case Watch: A Court in Pakistan Addresses U.S. Drone Attacks, Retrieved from http://www.opensocietyfoundations.org/voices/case-watch-court-pakistanaddresses-us-drone-attacks 20. March. 2017

Karl., Kaltenthaler, Miller, William \& Fair, Christine. 2012. 'The drone war: Pakistan public attitudes toward American drone strikes in Pakistan.' Retrieved from http://www.uakron.edu/dotAsset/4823799c-34eb-4b4f-992e ac4a2261e0c4.pdf

Karon, Tony. 05 November 2002. "Yemen Strike Opens New Chapter in War on Terror," Time, Retrieved from http://www.time.com/time/world/article/0,8599,387571,00.html 10. March. 2017

Krock, L. 2002, November. Spies that fly, timeline of UAVs. Retrieved from NOVA: http://www.pbs.org/wgbh/nova/spiesfly/uavs.html 12. April. 2017

Kugelman, Michael. May 2, 2012. "In Pakistan, Death Is Only One of the Civilian Costs of Drone Strikes," Huffington Post, Retrieved from http://www.huffingtonpost.com/michael-kugelman/in-pakistan-death-is only_b_1468916.html 10. April. 2017

Legality of U.S. Drone Strikes in Pakistan, Retrieved from http://crss.pk/downloads/Reports/Special-Posts/Legality-of-US-Drone-Strikes-inPakistan.pdf 10. April. 2017

Mazzetti, Mark. 2013. The Way of the Knife: The CIA, a Secret Army, and a War at the Ends of the Earth, New York: Penguin Press.

Miller, Greg. 23 October 2012. "Plan for hunting terrorists signals U.S. intends to keep adding names to kill lists," The Washington Post, Retrieved from http://www.washingtonpost.com/world/national-security/plan-for-huntingterrorists-signals-us-intends-to-keep-adding-names-to-killlists/2012/10/23/4789b2ae-18b3-11e2-a55c-39408fbe6a4b_story.html 20. March. 2017

Morely, Jefferson. 2012. "Air Force ramps up drone war," Retrieved from http://www.salon.com/2012/04/05/air_force_ramps_up_drone_war/10. April. 2017 
Nawaz, Shuja. Summer/Fall 2011. Drone Attack inside Pakistan: Wayang or Willing Suspension of Disbelief? Conflict \& Security, Georgetown Journal of International Affairs, Retrieved from http://www.newsfrommiddleeast.com/?xstart=b\&new=73356 10. April. 2017

Perlez, Jane \& Shah, Pir Zubair. April 4, 2010. Drones Batter Al Qaeda and Its Allies Within Pakistan, The New York Times, Retrieved from http://www.nytimes.com/2010/04/05/world/asia/05drones.html 15. March. 2017

Protocol Additional to the Geneva Conventions of 12 August 1949, and relating to the Protection of Victims of International Armed Conflicts (Protocol I), 8 June 1977. Retrieved from http://www2.ohchr.org/english/law/ccpr.htm 04. March. 2017

Rashid, Ahmed. 2012. Pakistan on the brink: the future of America, Pakistan and Afghanistan. London: Penguin Publishers.

Rehman, Abdul. October 2013. Impact of drone attacks in Pakistan and the war on terror: A consideration of the effects of drone attacks in Pakistan and whether they are helping or not to win the war on terror, Malmö University: Department of Global Political Studies International Relations III (61-90, 103E)

Risen, James and Vartabedian, Ralph. December 2, 1995. "Spy Plane Woes Create Bosnia Intelligence Gap," Los Angeles Times, Retrieved from http://articles.latimes.com/1995-12-02/news/mn-9494_1_military-intelligence 20. April. 2017

Rogers, Christopher. 2010. "Legality of U.S. Drone Strikes in Pakistan”, Center for Research and Security Studies.

Schifrin, Nick. December 30, 2011. "Was Teen Killed by CIA Drone a Militant - or Innocent Victim?" ABC News. Retrieved from. https://abcnews.go.com/Blotter/tariq-khan-killed-cia-drone/story?id=15258659 21. March 2017.

Schmitt, Eric and Mazzetti, Mark. 14 June 2011. "Pakistan arrests C.I.A. informants in Bin Laden raid", The New York Times, Retrieved from http://www.nytimes.com/2011/06/15/world/asia/15policy.html?pagewanted=all 20. March. 2017 
Shaheen, Sikander. 19 October 2011. “Army to toe parliament's line”, The Nation

Shane, Scott (August 11, 2011). "CIA Is Disputed on Civilian Toll in Drone Strikes," New York Times, Retrieved from http://www.nytimes.com/2011/08/12/world/asia/12drones.html?pagewanted=all 20. March. 2017

Shinwari, Naveed A. 2012. "Understanding FATA: 2011 - Attitudes towards Governance, Religion \& Society in Pakistan's Federally Administered Tribal Areas," Produced with the support of Community Appraisal \& Motivation Programme. Retrieved from http://understandingfata.org/22. March. 2017

Spymaster to 'talk tough' on drones”, 19 July 2012. The Nation, Retrieved from www.nation.com.pk/national/19-Jul...to-talk-tough-on-drones 02. March. 2017

Tyson, Ann S. 01 March 2002. "Does bin laden matter anymore?" The Christian Science Monitor, Retrieved from http://www.csmonitor.com/2002/0301/p01s02-usmi.html 20. March. 2017

United Nations Office of the High Commissioner for Human Rights. 28 May 2010. "Report of the Special Rapporteur on extrajudicial, summary or arbitrary executions, Philip Alston: Study on targeted killings," Retrieved from http://www2.ohchr.org/english/bodies/hrcouncil/docs/14session/A.HRC.14.24.Ad d6.pdf 20. March. 2017

Usmani, Dr. Zeeshan Ul Hassan. 2010. Retrieved from http://www.pakistanbodycount.org/bla.php. 22. March. 2017

Wheeler, Winslow. February 28, 2012. “The MQ-9's Cost and Performance,” Times, Retrieved from http://nation.time.com/2012/02/28/2-the-mq-9s-cost-andperformance/ 20. March. 2017

Williams, Brian. 2011. Afghanistan declassified: a guide to America's longest war, Pennsylvania: University of Pennsylvania Press.

Wood, Chris. September 25, 2012. Drones causing mass trauma among civilians, major study finds, Retrieved from http://www.uruknet.info 20. March. 2017 
Woodward, Bob. 2010. Obama's Wars, New York: Simon and Schuster

Zenko, Micah. January 2013. Reforming U.S. Drone Strike Policies, Council Special Report No. 65, Council on Foreign Relations, 